\title{
HIGH SCHOOL CHEMISTRY AND ENEM: A CURRICULAR COMPARISON
}

\section{ORIGINAL ARTICLE}

GORTZ, Julia Santana ${ }^{1}$, TATY, Salvador Rodrigues², FECURY, Amanda Alves ${ }^{3}$, DENDASCK, Carla Viana ${ }^{4}$, OLIVEIRA, Euzébio de ${ }^{5}$, DIAS, Claudio Alberto Gellis de Mattos $^{6}$

GORTZ, Julia Santana. Et al. High School Chemistry and Enem: A curricular comparison. Revista Científica Multidisciplinar Núcleo do Conhecimento. Year 06, Ed. 03, Vol. 03, pp. 89-99. March 2021. ISSN: 2448-0959, Access link: https://www.nucleodoconhecimento.com.br/education/curricular-comparison, DOI: 10.32749/nucleodoconhecimento.com.br/education/curricular-comparison

\section{ABSTRACT}

The National High School Exam (ENEM) is an assessment consisting of an essay and multiple choice questions. This assessment aims to measure the knowledge acquired during high school. The purpose of this article is to compare the content of the questions of the Chemistry component of the National High School Examination (ENEM) between the years 2014 to 2018 with the curriculum content of the technical chemistry course at the Federal Institute of Amapá (IFAP). The research was carried

\footnotetext{
${ }^{1}$ Student of the Technical Chemistry Course (high school) at the Institute of Basic, Technical and Technological Education of Amapá (IFAP).

${ }^{2}$ Chemist, Master in Chemistry (UFMA), Professor and researcher of the Chemistry Degree Course at the Basic, Technical and Technological Institute of Amapá (IFAP), Coordinator of the Technical Course in Chemistry (IFAP).

${ }^{3}$ Biomedical, PhD in Tropical Diseases (UFPA), Professor and researcher of the Medical Course at Campus Macapá, Federal University of Amapá (UNIFAP).

${ }^{4}$ Theologian, PhD in Psychoanalysis, researcher at the Center for Research and Advanced Studies - CEPA.

${ }^{5}$ Biologist, PhD in Tropical Diseases (UFPA), Professor and researcher at the Physical Education Course at, Federal University of Pará (UFPA).

${ }^{6}$ Biologist, PhD in Behavior Theory and Research (UFPA), Professor and researcher of the Chemistry Degree Course at the Basic, Technical and Technological Institute of Amapá (IFAP) and the Graduate Program in Professional and Technological Education (PROFEPT IFAP).
}

RC: 78640

Disponível em: https://www.nucleodoconhecimento.com.br/education/curricular- 
out using chemistry questions from the National High School Exam (ENEM) taken from the Super Professor (software) program. The content taught in the three years of the technical course in chemistry at the Federal Institute of Amapá (IFAP) meets the requirements of the National High School Exam (ENEM). The workload is also sufficient for the development of basic and technical disciplines. The content analysis demonstrates that, as it is a technical course, it provides in-depth knowledge, which increases the subsidy for carrying out the ENEM. This content is formed by theory and also by a great practical experience (laboratory). Practical knowledge helps enormously the fixation of learning and provides knowledge to discuss the contents.

Keywords: Teaching, Chemistry, ENEM, EPT, Curriculum.

\section{INTRODUCTION}

The National High School Exam (ENEM) is an assessment consisting of an essay and multiple choice questions. The questions correspond to the areas of Human Sciences and its Technologies (History, Geography, Philosophy and Sociology |); Natural sciences and their technologies (Physics, Chemistry and Biology); Languages, Codes and their technologies (Portuguese, Foreign Language, Arts and Physical Education); and mathematics and its technologies (Mathematics). This assessment aims to measure the knowledge acquired during high school (Moretto and Wittke, 2018).

A federal institute is an institution with the objective of meeting the need for qualified technical labor, so that students are better prepared for acquiring both basic knowledge and technical knowledge (Alves et al., 2013; Penha et al., 2020). There are currently 38 federal institutes that are present in all states (Brazil, 2018).

In 2007, on October 25, the Federal Technical School of Amapá (ETFAP) was created. On December 29, 2008, due to Law No. 11,892, ETFAP is transformed into

$\mathrm{RC}: 78640$

Disponível em: https://www.nucleodoconhecimento.com.br/education/curricular- 
the Federal Institute of Education, Science and Technology of Amapá (IFAP) (Brazil, 2019; Marques et al., 2020).

Its target audience is $50 \%$ of the high school level, technical course linked to high school (integrated, subsequent and concurrent); $30 \%$ of higher education, bachelor's and technological degrees and $20 \%$ for undergraduate degrees. Also having postgraduate studies: Lato Sensu and Stricto Sensu (Brazil, 2019; Castro et al., 2020).

The chemistry course was opened in 2017 , with 3 years of full-time. Its function is to train technicians capable of operating, controlling and monitoring industrial and laboratory processes. Maintain quality control of raw materials, inputs and products. Perform samples, chemical, physical-chemical and microbiological analyzes. Develop processes and products. The professionals trained in this course have the following fields of activity: chemical industries; Laboratories for quality control, certification of chemical, food and related products (Brazil, 2019a).

In the technical high school in chemistry offered by the Federal Institute of Amapá, the menu provides for the first year: general chemistry (chemistry in our daily lives, the evolution of atomic models and chemical bonds, inorganic functions; environmental problems and chemical reactions ) and technical materials (experimental chemistry, inorganic chemistry and organic chemistry). In the second year it is seen: general chemistry (solutions, exothermic and endothermic reactions, speed, factors, balance and displacement and electrochemistry) and technical matters (physical-chemical, analytical chemistry, instrumental analysis and corrosion). Finally in the third year: general chemistry (organic chemistry, hydrocarbons, oxygenated, nitrogenous and mixed functions and organic properties) and technical materials (petroleum and polymers, industrial chemical processes and biofuel technology) (Brazil, 2016).

RC: 78640

Disponível em: https://www.nucleodoconhecimento.com.br/education/curricular- 
The content of Enem's chemistry questions is divided into 10 main units, which are: Chemical transformations (where the subjects of atomic number, mass number, isotopes, atomic mass, periodic table and chemical reactions are included); Representation of chemical transformations (topic that includes balancing chemical equations and stoichiometric calculations); Materials, their properties and uses (which includes material properties, physical states of materials, changes in state, mixtures and intermolecular forces); Water (which includes solutions, acids, bases, salts and oxides, nomenclature and indicators); Chemical transformations and energy (where contents such as enthalpy, thermochemical equations, Hess's law, cell and electrolysis are inserted); Dynamics of chemical transformations (which includes reaction speed and activation energy); Chemical transformation and equilibrium (which includes the subjects of equilibrium constant, acid-base balance and $\mathrm{pH}$, salt solubility and hydrolysis); Carbon compounds (includes organic functions, hydrocarbons and polymers); Relations of chemistry with technologies, society and the environment (includes the subject of pollution); Chemical energies in everyday life (includes the subjects of oil, natural gas and coal) (Brasil, 2015).

\section{GOALS}

Compare the content of the questions of the Chemistry component of the National High School Examination (ENEM) between the years 2014 to 2018 with the curriculum content of the technical chemistry course at the Federal Institute of Amapá (IFAP).

\section{METHODOLOGY}

The research was carried out using chemistry questions from the National High School Exam (ENEM) taken from the Super Professor program (software), acquired from Interbits Informática (https://www.sprweb.com.br/mod_superpro/index.php) . The chemical discipline and the years 2014 to 2018 were selected in the program. The questions were classified according to the program. Subsequently, a comparison

RC: 78640

Disponível em: https://www.nucleodoconhecimento.com.br/education/curricular- 
was made between these and the syllabus of the chemical component of the technical course at the Federal Institute of Amapá (IFAP). The bibliographic research was carried out on scientific articles, on computers of the Institute at the Federal Institute of Education, Science and Technology of Amapá, Campus Macapá, located at Rodovia BR 210 KM 3, s / n - Bairro Brasil Novo. CEP: 68.909-398, Macapá, Amapá, Brazil. The data was compiled in the Excel application, part of the Microsoft Corporation's Office suite.

\section{RESULTS}

Table 1 shows the content of ENEM chemistry questions between 2014 and 2018, by quantity and percentage of questions. These questions correspond to $78.82 \%$ of the total questions in the period. Questions about enzymes, carbohydrates, indicators, changes in state, symbols, pollution and physico-chemical properties do not appear in the period (0.00\%). Questions about atom structure, chemical kinetics, density, colligative properties, solutions, periodic classification, reaction equation and balance, inorganic functions, laboratory practices, substance and mixture, carbon chains, flat isomerism, oil and polymers appear 1.18\%. Questions about solution concentrations, chemical or ionic balance, salt hydrolysis, redox and functions are 2.35\%. Questions about chemical bonds and molecular geometry, radioactivity and spatial isomerism correspond to $3.53 \%$. Stoichiometric calculation and separation of mixtures correspond to $4.71 \%$ of the questions. Questions about thermochemistry and organic reactions are $7.06 \%$. Intermolecular and electrochemical forces appear $8.24 \%$.

$\mathrm{RC}: 78640$

Disponível em: https://www.nucleodoconhecimento.com.br/education/curricular- 
Table 1 Classification of the content of ENEM chemistry questions between 2014 and 2018 , by quantity and percentage of questions.

\begin{tabular}{|c|c|c|}
\hline \multicolumn{3}{|c|}{ Classificaçăo do autor após analise de conteúdo } \\
\hline Conteúdo de Química & Quantidade & Porcentagem \\
\hline Enzimas & 0 & $0.00 \%$ \\
\hline Hidratos de Carbono & 0 & $0.00 \%$ \\
\hline Indicadores & 0 & $0.00 \%$ \\
\hline Mudanças de Estado & 0 & $0.00 \%$ \\
\hline Símbolos & 0 & $0.00 \%$ \\
\hline Poluição & 0 & $0.00 \%$ \\
\hline Propriedades Físico-Químicas & 0 & $0.00 \%$ \\
\hline Estrutura do atomo & 1 & $1.18 \%$ \\
\hline Cinética Química & 1 & $1.18 \%$ \\
\hline Densidade & 1 & $1.18 \%$ \\
\hline Propriedades Coligativas & 1 & $1.18 \%$ \\
\hline Soluções & 1 & $1.18 \%$ \\
\hline Class ificação Periódica & 1 & $1.18 \%$ \\
\hline Equacionamento e Balanceamento de Reações & 1 & $1.18 \%$ \\
\hline Funções Inorgânicas & 1 & $1.18 \%$ \\
\hline Práticas de Laboratório & 1 & $1.18 \%$ \\
\hline Substância e Mistura & 1 & $1.18 \%$ \\
\hline Cadeias Carbônicas & 1 & $1.18 \%$ \\
\hline Isomeria Plana & 1 & $1.18 \%$ \\
\hline Petróleo & 1 & $1.18 \%$ \\
\hline Polímeros & 1 & $1.18 \%$ \\
\hline Concentraçôes das Soluções & 2 & $2.35 \%$ \\
\hline Equilíbrio Químico ou lônico & 2 & $2.35 \%$ \\
\hline Hidrólise de Sa is & 2 & $2.35 \%$ \\
\hline Óxido-redução & 2 & $2.35 \%$ \\
\hline Funções & 2 & $2.35 \%$ \\
\hline Ligações Químicas e Geometria Molecular & 3 & $3.53 \%$ \\
\hline Radioatividade & 3 & $3.53 \%$ \\
\hline Isomeria Espacial & 3 & $3.53 \%$ \\
\hline Cálculo Estequiométrico & 4 & $4.71 \%$ \\
\hline Separação de Misturas & 4 & $4.71 \%$ \\
\hline Termoquímica & 6 & $7.06 \%$ \\
\hline Reações Orgânicas & 6 & $7.06 \%$ \\
\hline Forças intermoleculares & 7 & $8.24 \%$ \\
\hline Eletroquímica & 7 & $8.24 \%$ \\
\hline
\end{tabular}

RC: 78640

Disponível em: https://www.nucleodoconhecimento.com.br/education/curricular- 
Table 2 shows the overlapping content of ENEM chemistry questions between 2014 and 2018, by quantity and percentage of questions. The overlapping questions represent $21.18 \%$ of the total exam, in the period. The questions Intermolecular forces + Physical-Chemical Properties, Intermolecular forces + Colligative properties, Intermolecular forces + Separation of mixtures, Chemical bonds and molecular geometry + periodic classification, Hydrolysis of salts + Equation and balance of reactions + Inorganic functions, Chemical or ionic balance + Polymers, Carbohydrates + Oxide-reduction, Hydrolysis of salts + Indicators, Symbols + Substance and mixture, Equation and balance of reactions + Pollution and Pollution + Carbon chains appear 1.18\%. The problems of Enzymes + Organic reactions, Concentrations of solutions + Solutions account for $2.35 \%$.

Table 2 Classification of the overlapping content of ENEM chemistry questions between 2014 and 2018, by quantity and percentage of questions. Overlapping questions represent $21.18 \%$

\begin{tabular}{l|c|c|}
\hline \multicolumn{3}{c}{ Classificação do autor após analise de conteúdo sobreposto } \\
\hline \multicolumn{1}{c|}{ Conteúdo de Química } & Quantidade & Porcentagem \\
\hline Forças intermoleculares + Propriedades Fisico-Quimicas & 1 & $1.18 \%$ \\
\hline Forças intermoleculares + propriedades coligativas & 1 & $1.18 \%$ \\
\hline Forças Intermoleculares + Separação de Misturas & 1 & $1.18 \%$ \\
\hline Forças Intermoleculares + Mudanças de Estado & 1 & $1.18 \%$ \\
\hline Ligações Químicas e Geometria Molecular + Classificação Periódica & 1 & $1.18 \%$ \\
\hline Hidrólise de Sais + Equa cionamento e Balanceamento de Reações + & 1 & $1.18 \%$ \\
\hline Funções Inorgânicas & 1 & $1.18 \%$ \\
\hline Equilíbrio Químico ou lônico + Polímeros & 1 & $1.18 \%$ \\
\hline Hidratos de Carbono + Óxido-redução & 1 & $1.18 \%$ \\
\hline Hidrólise de Sais + Indicadores & 1 & $1.18 \%$ \\
\hline Simbolos + Substância e Mistura & 1 & $1.18 \%$ \\
\hline Equacionamento e Balanceamento de Reações + Poluição & 1 & $1.18 \%$ \\
\hline Poluição + Cadeias Carbônicas & 1 & $2.35 \%$ \\
\hline Enzimas + Reações Orgânicas & 2 & $2.35 \%$ \\
\hline Concentrações das Soluções + Soluções & 2 & $2.35 \%$ \\
\hline Cadeias Carbônicas + Reações Orgânicas & 2 & \\
\hline
\end{tabular}

RC: 78640

Disponível em: https://www.nucleodoconhecimento.com.br/education/curricular- 
The subjects of the chemistry menu of the technical course in chemistry at IFAP, by year and unit (referring to each two-month period), are shown in table 3. In the chemistry course, the subjects are divided between normal high school and technical subjects, which are specific to the course. In the subjects of the standard curriculum table, the component used in the three years is general chemistry. Its total workload is 240 hours, 80 hours each year. In the first year your first unit is given in 15 hours, the second unit in 20 hours, the third in 25 hours and the fourth in 20 hours. In the second year the first content is given in 15 hours, the second content in 15 hours, the third in 25 hours and the fourth in 25 hours. In the third year, the first unit has a workload of 15 hours, the second unit has a workload of 20 hours, the third of 30 hours and the fourth of 15 hours.

The other subjects (technical curricular) mentioned in table 3 are technical subjects specific to the course, these are semiannual and have a total workload of 80 hours per semester each. In the first year the subjects are cited: experimental chemistry, which has a workload of 10 hours, 20 hours, 25 hours and 25 hours for units one, two, three and four respectively; inorganic chemistry, with a workload of 15 hours for the first unit, 15 hours for the second unit, 25 hours for the third unit and 25 hours for the fourth unit; organic chemistry, whose first unit is given in 25 hours, the second unit in 15 hours, the third in 20 hours and the fourth in 20 hours. In the second year the technical subjects are as follows: Physico-chemistry, with its first unit given in 25 hours, its second unit given in 20 hours, the third in 20 hours and the fourth in 15 hours; analytical chemistry, with 18 hours for its first unit, 20 hours for the second unit, 23 hours for the third unit and 19 hours for the fourth unit; instrumental analysis, with its four units are given in, respectively, 10 hours, 20 hours, 25 hours and 25 hours; corrosion, where your first unit is given in 10 hours, your second unit is given in 25 hours, your third unit is given in 20 hours and your fourth in 25 hours. In the third year, the specific disciplines mentioned in the table are: petroleum and polymers, with their units given in 18 hours, 22 hours, 22 hours and 18 hours respectively; industrial chemical processes, with its first unit given in 25 hours, the

RC: 78640

Disponível em: https://www.nucleodoconhecimento.com.br/education/curricular- 
second unit given in 20 hours, the third unit in 20 hours and the fourth in 15 hours; biofuel technology, with a workload of 25 hours for the first unit, 25 hours for the second unit, 10 hours for the third and 20 hours for the fourth.

RC: 78640

Disponível em: https://www.nucleodoconhecimento.com.br/education/curricularcomparison 
Table 3. Subjects of the chemistry menu of the technical course in chemistry at IFAP, by year and unit.

DISGPLINA CURRICULAR PADRĀO

\begin{tabular}{|c|c|c|c|c|c|c|}
\hline \multirow[b]{2}{*}{ Unidade } & \multicolumn{6}{|c|}{ Ano } \\
\hline & $1^{\circ}$ ANO & $\begin{array}{c}n^{\circ} \text { de } \\
\text { horas aula }\end{array}$ & $2^{\circ}$ ANO & de horas at & $3^{\circ} \mathrm{ANO}$ & $\begin{array}{c}\mathbf{n}^{\circ} \text { de } \\
\text { horas aula }\end{array}$ \\
\hline I & $\begin{array}{c}\text { A. Quimica emnosso } \\
\text { cotidiano }\end{array}$ & 15 horas & Sohções & 15 horas & Quimica Orgânica & 15 horas \\
\hline II & $\begin{array}{l}\text { A evobção dos } \\
\text { modelos atômicos e } \\
\text { ligacões Qvímic as. }\end{array}$ & 20 horas & $\begin{array}{l}\text { Reações exotérmicas } \\
\text { e endotérmicas }\end{array}$ & 15 horas & Hidrocarb onetos & 20 horas \\
\hline III & $\begin{array}{c}\text { Funções Inorgânicas } \\
\text { e problemas } \\
\text { anbientais }\end{array}$ & 25 horas & $\begin{array}{c}\text { Velocidiade, fatores, } \\
\text { equilibrio e } \\
\text { deslocamento }\end{array}$ & 25 horas & $\begin{array}{l}\text { Funções Oxigenadas, } \\
\text { nitrogenadas e mis tas }\end{array}$ & 30 horas \\
\hline IV & Reações Quimicas & 20 horas & Eletro-Quimica & 25 horas & $\begin{array}{c}\text { Propriedades } \\
\text { Orgânicas }\end{array}$ & 15 horas \\
\hline & & 80 horas & & 80 horas & & 80 horas \\
\hline
\end{tabular}

DISCIPLINA CURRICULAR TÉCNICA - 19 ANO

\begin{tabular}{|c|c|c|c|c|c|c|}
\hline \multirow[b]{2}{*}{ Unidade } & \multicolumn{6}{|c|}{ Ano } \\
\hline & $\begin{array}{c}\text { Quimica } \\
\text { Experimental }\end{array}$ & $\begin{array}{c}\mathbf{n}^{\circ} \text { de } \\
\text { horas aula }\end{array}$ & $\begin{array}{c}\text { Quimica } \\
\text { Inorgânica }\end{array}$ & $\begin{array}{c}\mathbf{n}^{\circ} \text { de } \\
\text { horas aula }\end{array}$ & $\begin{array}{l}\text { Quimica } \\
\text { Orgânica }\end{array}$ & $\begin{array}{c}\mathbf{n}^{\circ} \text { de } \\
\text { horas aula }\end{array}$ \\
\hline I & $\begin{array}{l}\text { Introdução aos } \\
\text { trabalhos em } \\
\text { laboratório. }\end{array}$ & 10 horas & $\begin{array}{c}\text { Quimica dos não } \\
\text { metais }\end{array}$ & 15 horas & $\begin{array}{c}\text { Introdução a } \\
\text { mecanismo de reação }\end{array}$ & 25 horas \\
\hline II & $\begin{array}{l}\text { Obtenção e us o de } \\
\text { calor }\end{array}$ & 20 horas & Quimica dos metais & 15 horas & Ácidos e Bas es & 15 horas \\
\hline III & $\begin{array}{c}\text { Process os de } \\
\text { separação de mis turas }\end{array}$ & 25 horas & $\begin{array}{l}\text { Compostos de } \\
\text { coordenação }\end{array}$ & 25 horas & $\begin{array}{l}\text { Reações de adição- } \\
\text { eliminação } \\
\text { nucleofilica em } \\
\text { carbono acilico }\end{array}$ & 20 horas \\
\hline IV & $\begin{array}{c}\text { Estudo das reações } \\
\text { Quimicas }\end{array}$ & 25 horas & $\begin{array}{l}\text { Estrutura de sólidos } \\
\text { cristalinos e amorfos }\end{array}$ & 25 horas & $\begin{array}{l}\text { Reações de } \\
\text { substituição } \\
\text { eletrofitica em } \\
\text { aromáticos }\end{array}$ & 20 horas \\
\hline & & 80 horas & & 80 horas & & 80 horas \\
\hline
\end{tabular}

\begin{tabular}{|c|c|c|c|c|c|c|c|c|}
\hline \multirow[b]{2}{*}{ Unidade } & \multicolumn{8}{|c|}{ Ano } \\
\hline & Fisico Quimira & $\begin{array}{c}\mathbf{n}^{\circ} \text { de } \\
\text { horas aula }\end{array}$ & Quimica Analítica & $\begin{array}{c}\mathbf{n}^{\circ} \text { de } \\
\text { horas aula }\end{array}$ & $\begin{array}{c}\text { Análise } \\
\text { Instrumental }\end{array}$ & $\begin{array}{c}\mathbf{n}^{\circ} \text { de } \\
\text { horas aula }\end{array}$ & Corrosão & $\begin{array}{c}n^{\circ} \text { de horas } \\
\text { aula }\end{array}$ \\
\hline I & $\begin{array}{c}\text { Solvções, Dispersōes } \\
\text { e Propriedades } \\
\text { Coligativas }\end{array}$ & 25 horas & $\begin{array}{c}\text { Introduçāo, Tecnicas } \\
\text { e Métodos }\end{array}$ & 18 horas & $\begin{array}{c}\text { Introdução a aná lise } \\
\text { instrumental }\end{array}$ & 10 horas & Introd vção a corro são & 10 horas \\
\hline II & Equilibrio Quimico & 20 horas & $\begin{array}{l}\text { Titulometria de } \\
\text { neutralizaçăo e } \\
\text { precipitaçăio }\end{array}$ & 20 horas & $\begin{array}{c}\text { Métodos } \\
\text { eletroan aliticos }\end{array}$ & 20 horas & $\begin{array}{c}\text { Princ ipios básicos da } \\
\text { corrosảo } \\
\text { eletroQu ímica }\end{array}$ & 25 horas \\
\hline III & Cinética Quimica & 20 horas & $\begin{array}{c}\text { Titulometria de } \\
\text { complexaça âo e oxi- } \\
\text { redução }\end{array}$ & 23 horas & $\begin{array}{c}\text { Métodos } \\
\text { espectros cópicos }\end{array}$ & 25 horas & $\begin{array}{c}\text { Princípios básicos da } \\
\text { corrosảo Quimica }\end{array}$ & 20 horas \\
\hline IV & \begin{tabular}{|c|} 
Es tudo dos \\
Proces sos de Troca \\
de Calor nos \\
Equilibrios \\
\end{tabular} & 15 horas & Laboratónio, Cáculos & 19 horas & $\begin{array}{c}\text { Métodos } \\
\text { cromatográficos }\end{array}$ & 25 horas & $\begin{array}{c}\text { Resistênc ia à } \\
\text { corros ào e proteçăo } \\
\text { anticorro siva }\end{array}$ & 25 horas \\
\hline & & 80 horas & & 80 horas & & 80 horas & & 80 horas \\
\hline
\end{tabular}

RC: 78640

Disponível em: https://www.nucleodoconhecimento.com.br/education/curricular- 
DISCIPLINA CURRICULAR TÉCNICA - 3 ANO

\begin{tabular}{|c|c|c|c|c|c|c|}
\hline \multirow[b]{2}{*}{ Unidade } & \multicolumn{6}{|c|}{ Ano } \\
\hline & $\begin{array}{l}\text { Petróleo e } \\
\text { Polímeros }\end{array}$ & $\begin{array}{c}n^{\circ} \text { de } \\
\text { horas aula }\end{array}$ & $\begin{array}{l}\text { Processos } \\
\text { Qúnicos } \\
\text { Industriais }\end{array}$ & $\begin{array}{c}n^{\circ} \text { de } \\
\text { horas aula }\end{array}$ & $\begin{array}{c}\text { Tecnologia de } \\
\text { Biocombustiveis }\end{array}$ & $\begin{array}{c}\mathbf{n}^{\circ} \text { de } \\
\text { horas aula }\end{array}$ \\
\hline I & $\begin{array}{c}\text { Process os } \\
\text { tecnológicos de } \\
\text { petróleo e polimeros e } \\
\text { Leg is lação pertinente }\end{array}$ & 18 horas & $\begin{array}{l}\text { Tratamento de água, } \\
\text { Importancia do } \\
\text { Tratamento de } \\
\text { Efluentes, Parâmetros } \\
\text { de polvição hidrica e } \\
\text { Classificação de } \\
\text { residuos }\end{array}$ & 25 horas & $\begin{array}{l}\text { Etapas Quimicas da } \\
\text { Sintese de Etanol e do } \\
\text { Biodiesel; Anális e } \\
\text { Quimica de Qualidade } \\
\text { de Produção de Mini - } \\
\text { Usinas Pequeno, } \\
\text { Médio e Grande Porte }\end{array}$ & 25 horas \\
\hline II & $\begin{array}{l}\text { Controle de qualidade } \\
\text { e Fundamentos do } \\
\text { petróleo e dos } \\
\text { polimeros }\end{array}$ & 22 horas & $\begin{array}{c}\text { Tratamento e } \\
\text { disposição final de } \\
\text { efluentes de } \\
\text { residvo, Formas de } \\
\text { tratamentos, Tipos de } \\
\text { tratamento e descarte } \\
\text { e Tpos de } \\
\text { equipamentos } \\
\end{array}$ & 20 horas & $\begin{array}{c}\text { Produção e Análise } \\
\text { Quimica de } \\
\text { Biocombus tiveis em } \\
\text { Escala Laboratoriale } \\
\text { Industrial }\end{array}$ & 25 horas \\
\hline ШI & $\begin{array}{l}\text { Indústria do petróleo } \\
\text { e petroQvimica e } \\
\text { Logis tica do petróleo }\end{array}$ & 22 horas & $\begin{array}{c}\text { Programas de } \\
\text { reutilização, } \\
\text { Resolvção de } \\
\text { problemas de } \\
\text { produção e } \\
\text { qualidade de } \\
\text { a limentos, Otimiza ção } \\
\text { na produção de } \\
\text { oleaginos as e açúcar }\end{array}$ & 20 horas & $\begin{array}{l}\text { Produção de Bio- } \\
\text { Etanol e Biodiesel }\end{array}$ & 10 horas \\
\hline IV & $\begin{array}{l}\text { Produção de } \\
\text { polimeros e } \\
\text { Reciclagem de } \\
\text { polimeros }\end{array}$ & 18 horas & $\begin{array}{c}\text { Otimização na } \\
\text { produção de álcool, } \\
\text { Oleaginos as da região } \\
\text { e Reações Quimicas } \\
\text { dos mais importantes } \\
\text { processos industriais }\end{array}$ & 15 horas & $\begin{array}{l}\text { Aspectos } \\
\text { operacionais de } \\
\text { usinas de etanol } \\
\text { biodiesele, } \\
\text { combus tiveis de } \\
\text { Terceira geração }\end{array}$ & 20 horas \\
\hline & & 80 horas & & 80 horas & & 80 horas \\
\hline
\end{tabular}

The sum of ENEM chemistry questions between 2014 and 2018, by degree of difficulty, per year appears in figure 1. The number of questions with medium difficulty increased from seven (7) in 2014 to twelve (12) in 2015. In both subsequent years there was a reduction, with seven (7) questions in 2016 and five (5) in 2017. In 2018 there was a small increase, totaling six (6) questions. In matters of high complexity, there was a reduction from ten (10) questions in 2014 to five (5) in 2015. From then on there was an increase in the following two years, with ten (10) in 2016

RC: 78640

Disponível em: https://www.nucleodoconhecimento.com.br/education/curricular- 
and twelve (12) in 2017 In 2018 there was a small drop in the number, eleven (11) questions).

Figure 1 Shows the sum of ENEM chemistry questions between 2014 and 2018, by degree of difficulty,

by

year

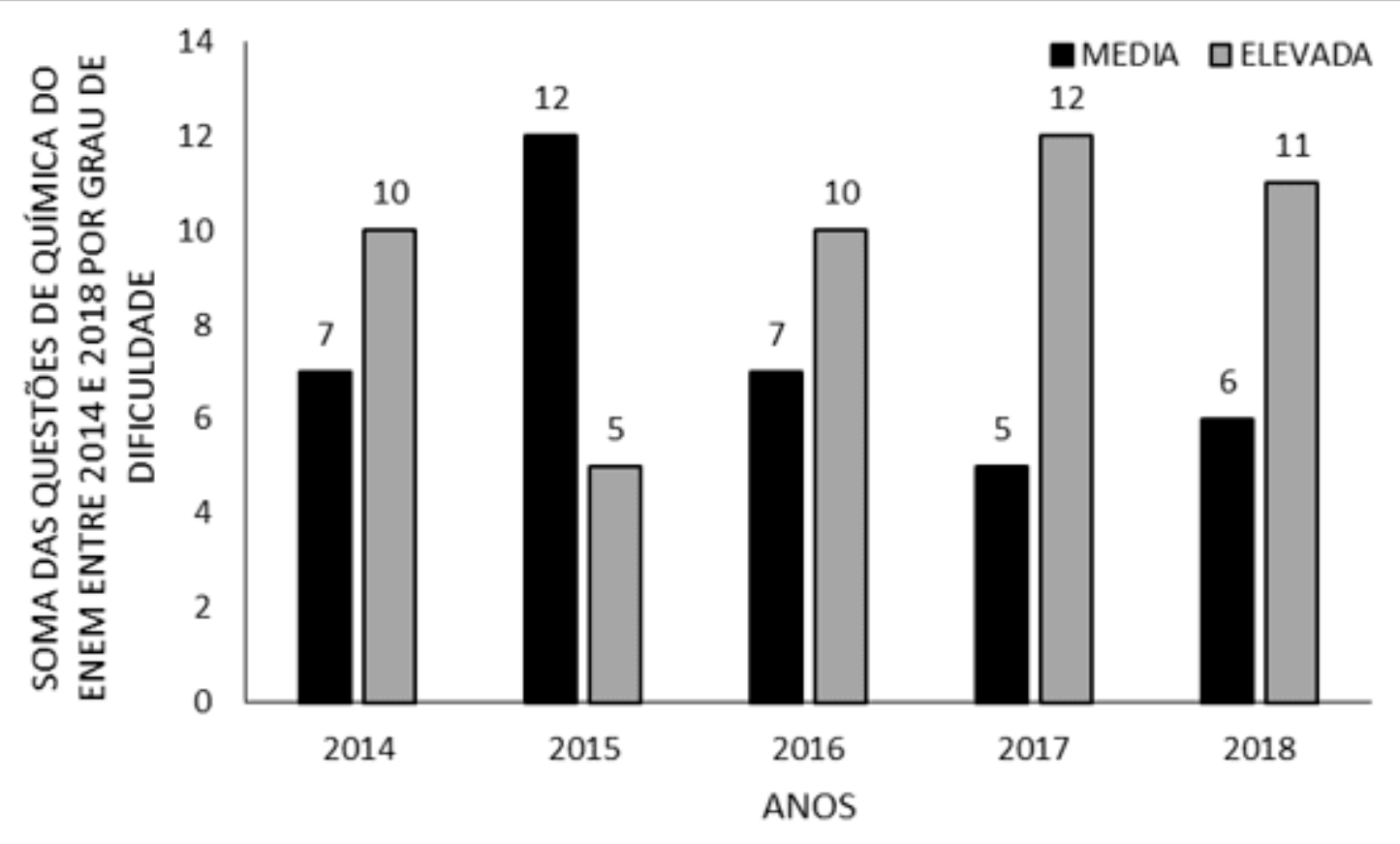

\section{DISCUSSION}

The difference present in the ENEM tests assessed, as to the percentage of each content (Table 1), probably occurs due to some of them being more present in the students' daily lives (such as organic reactions and the links between them) than others (indicators, changes in state, symbology). ENEM values to contextualize its questions (Hipólito and Silveira, 2011; Silveira et al., 2014).

The contents of ENEM are superimposed because they seek an integration between the internal topics of the chemistry curriculum matrix and between these topics and the other disciplines (interdisciplinarity and transversality) (Table 2). This mixture of contents helps them to get closer to the students' daily lives. It also helps in changing

RC: 78640

Disponível em: https://www.nucleodoconhecimento.com.br/education/curricular- 
the curriculum to something less plastered and more transversal (Hipólito and Silveira, 2011).

This table further demonstrates that most intradisplinary questions are about enzymes, organic reactions, solutions and concentration of solutions. This is possibly due to the fact that, physiologically, most living things function due to the chemistry of their organic structure. So, once again, questions like this are closer to the students' daily lives (Leite and Velani, 2019).

The contents may have different workloads (Table 3) due to differences in complexity and also the ability to contextualize the content. Contextualizing the content is important for their understanding and understanding. As each teacher has their own unique way of teaching them, there may be a difference in the curriculum time programmed in the planning with the real time to teach them (Pontes et al., 2008).

The area of natural sciences has the greatest weight for the health and biological fields in most public universities in Brazil, such as USP, one of the most prestigious universities in the country. The courses in the health area are highly coveted, especially due to their remuneration. Chemistry questions probably seek to maintain a higher difficulty (Figure 1) so that candidates with more knowledge in this area of great importance for the course enter with more knowledge in these (Casoni, 2021; Ufpe, 2021).

\section{CONCLUSION}

The content taught in the three years of the technical course in chemistry at the Federal Institute of Amapá (IFAP) meets the requirements of the National High School Exam (ENEM).

$\mathrm{RC}: 78640$

Disponível em: https://www.nucleodoconhecimento.com.br/education/curricular- 
The workload of the high school technical course in chemistry at IFAP is also sufficient for the development of basic and technical disciplines, and also provides a good basis for ENEM

The content analysis of the course has chemistry from the IFAP demonstrates that, as it is a technical course, it provides in-depth knowledge, which increases the subsidy for carrying out the ENEM. This content is formed by theory and also by a great practical experience (laboratory). Practical knowledge helps enormously the fixation of learning and provides knowledge to discuss the contents.

Therefore, the curricular content of this technical course meets the basic requirements of the National Exam.

\section{REFERENCES}

ALVES, N. B.; PALMA, L. C.; SILVA, T. N. Educação para a sustentabilidade: a construção de caminhos no Instituto Federal de Educação, Ciência e Tecnologia do Rio Grande do Sul (IFRS). Ram, Rev. Adm. Mackenzie, v. 14, n. 3, p. 83-118, 2013.

BRASIL. Matriz de Referência Enem. Brasilia DF, 2015. Disponível em: < http://download.inep.gov.br/download/enem/matriz_referencia.pdf >. Acesso em: 25 mar 2020.

. Curso Técnico de Nível Médio em Química na Forma Integrada Regime Integral: Plano de Curso. Macapá AP, 2016. Disponível em: < https://portal.ifap.edu.br/index.php/publicacoes/item/1100-resolucao-n-20-2018consup $>$.

. Expansão da Rede Federal. Rede Federal de Educação Profissional, Científica e Tecnológica. 2018. Disponível em: < http://redefederal.mec.gov.br/expansao-da-rede-federal >. Acesso em: 20 abr 2020.

RC: 78640

Disponível em: https://www.nucleodoconhecimento.com.br/education/curricular- 
Histórico. Macapá AP, 2019. Disponível em: < http://portal.ifap.edu.br/index.php/quem-somos/historico >. Acesso em: 24 abr. 2020. Curso Técnico em Química - Integrado - Campus Macapá. Macapá AP, 2019a. Disponível em: http://www.ifap.edu.br/index.php/component/content/article?id=398 >. Acesso em: 24 abr. 2020.

CASONI, L. A. SiSU Simulator. 2021. Disponível em: < https://sisusimulator.com.br/usp/faculdade-de-medicina-da-universidade-de-saopaulo-fm/medicina-bacharelado >. Acesso em: 24 fev 2021

CASTRO, G. N. V. et al. Análise de Eficiência Acadêmica dos cursos subsequentes, nas modalidades à distância e presencial, ofertados pelo Instituto Federal do Amapá (2018). Research, Society and Development, v. 9, n. 8, p. e208985262, 2020. https://rsdjournal.org/index.php/rsd/article/view/5262

HIPÓLITO, A. F.; SILVEIRA, H. E. D. As questões de Química do Exame Nacional do Ensino Médio (ENEM) em um enfoque transversal e interdisciplinar. 2011. Disponível em: < http://abrapecnet.org.br/atas_enpec/viiienpec/resumos/R0237-1.pdf >. Acesso em: 11 fev 2021.

LEITE, K. D. C.; VELANI, V. Divertindo-se com a química: o ensino e a aprendizagem por meio do lúdico. Braz. J. of Develop., v. 5, n. 11, p. 25115-25133, 2019.

MARQUES, J. D. C. et al. Nível Médio Técnico e Cursos de Graduação: comparativo de vagas e ingressantes no Instituto Federal do Amapá, Brasil (20172018). Research, Society and Development, v. 9, n. 8, p. e228985375, 2020. https://rsdjournal.org/index.php/rsd/article/view/5375

RC: 78640

Disponível em: https://www.nucleodoconhecimento.com.br/education/curricular- 
MORETTO, M.; WITTKE, C. I. Capacidades de linguagem desenvolvidas em estudantes do ensino médio a partir de uma dinâmica de produção de textos focada no ENEM. Diálogo das Letras, v. 7, n. 2, p. 155 - 172, 2018.

PENHA, A. C. F. M. et al. Matrículas da Educação Especial na Educação Profissional Técnica de Nível Médio no Estado do Amapá (2015-2018). Research, Society and Development, v. 9, n. 7, p. e881974867, 2020. https://rsdjournal.org/index.php/rsd/article/view/4867

PONTES, A. N. et al. O Ensino de Química no Nível Médio: Um Olhar a Respeito da Motivação. XIV Encontro Nacional de Ensino de Química (XIV ENEQ) Curitiba PR: Universidade Federal do Paraná 2008.

SILVEIRA, F. L.; STILCK, J.; BARBOSA, M. Comunicações: Manifesto sobre a qualidade das questões de Física na Prova de Ciências da natureza no Exame Nacional de Ensino Médio. Caderno Brasileiro de Ensino de Física, v. 31, n. 2, p. 473-479, 2014.

UFPE. Relação dos Cursos com novos Pesos e Notas Mínimas do ENEM 2019 que serão aplicados no Processo Seletivo UFPE| SiSU 2020. 2021. Disponível em: < https://www.ufpe.br/documents/38970/2199517/Pesos+e+notas+m\%C3\%ADnimas+ ENEM_UFPE+2020_+Mudan\%C3\%A7as+nos+cursos_03.06.19.pdf/85759192-f4cc4817-8541-026a5e06f7c4 >. Acesso em: 24 fev 2021.

Posted: March, 2021

Approved: March, 2021

RC: 78640

Disponível em: https://www.nucleodoconhecimento.com.br/education/curricular- 